GLOBAL JOURNAL OF EDUCATIONAL RESEARCH VOL 18, 2019: 47-56

COPYRIGHT@ BACHUDO SCIENCE CO. LTD PRINTED IN NIGERIA. ISSN 1596-6224 www.globaljournalseries.com; Info@globaljournalseries.com

\title{
UTILIZATION OF INFORMATION AND COMMUNICATION TECHNOLOGY (ICT) AND LIBRARY OPERATIONS IN STATE UNIVERSITY LIBRARIES IN SOUTH-SOUTH NIGERIA
}

EMMANUEL UBI OMINI AND JACOB E. ESIN

(Received 16, October 2017; Revision Accepted 10, September 2018)

\begin{abstract}
This study examined utilization of information and communication technology (ICT) and library job operations in state university libraries in South-South Nigeria. Two hypotheses were formulated to guide the study. Survey research design was used. The population for the study constituted 143 librarians (professionals and paraprofessionals). A sample of 93 librarians was selected using purposive sampling technique. The instrument was validated by experts. The research data was analyzed with descriptive (mean and standard deviation) and inferential statistics (One-Way ANOVA). All hypotheses were tested at 0.05 level of significance. The findings revealed that there was a significant influence of online databases services on library job operations, $\left(\mathrm{f}=4.447^{*}, \mathrm{P}<.05, \mathrm{df}=2,728, \mathrm{~F}\right.$-critical $\left.=3.00\right)$ and there was a significant influence of CD-ROM services on library job operations, $\left(f=2.671^{*}, P<.05, d f=2,728, F\right.$ critical=3.00). From the result of the study, it was recommended among others that librarians should utilize more ICT tools to facilitate their job operations in the library.
\end{abstract}

KEYWORD: Utilization of ICT, Online databases Service, CD-ROM Service, Library job operations, State University, Libraries, South-South Nigeria.

\section{INTRODUCTION}

The switch from conventional to modern tools has changed the ways routine library operations like cataloguing, circulation, assigning of core numbers to new arrivals, indexing, etc. are carried out in terms of productivity and efficiency. A range of practices do take place in collection management. There includes selection, acquisition, interlibrary loan, preservation and cataloguing of information resources. These are all routine library operation that are carried out by librarians in the library. It is becoming impracticable for librarians to perform their job operations without carrying out these practices.
Librarians now perform their library operations utilizing Information and communication technology which offers fast and increased alternatives to information resource gathering and research orientation bringing about accuracy and efficiency in university libraries and the entire library environment. This development as observed by Ani, Esin and Edem (2005) has created a shift from traditional information environment to electronic environment such as computer use, internet use, online services as well as online databases to library operations.

The emergence of ICTs and other digital technologies and networks has dramatically brought innovations in librarianship. According to

Emmanuel Ubi Omini, Department of Library and Information Science University of Calabar-Calabar. Jacob E. Esin, Department of Library and Information Science University of Calabar-Calabar. 
Ani and Edem (2015), the adoption and integration of ICTs has tremendously brought efficiency and effectiveness in the services and operations in the library. It has offered librarians and information users, different options that can be used in carrying out library routine operations which will give them fast and accurate results. Books that takes over three months to catalogue now within one week through the use of computer and internet services. It is becoming unrealistic for librarians to achieve success in their job operations without carrying out these functions.

Librarians now perform their library operations utilizing ICT which offers fast and increased alternatives to information resource gathering and research orientation bringing about accuracy and efficiency in university libraries and the entire library environment (Edem, Emmanuel and Usoro, 2017). Librarians now send e-mails reminders to users that borrowed library books reminding them the due date to return the books rather than the issuance of manual library card. All library records and transactions during acquisition of library books can now be done electronically with the aid of information and communication technology tools. Also, library collections are being transformed into CD-ROMs with ease. The conventional methods where collections are being destroyed by fire, mutilated by users and occupies large space has been transformed.

Librarians now utilize these services anytime and anywhere on the internet enabled facilities which is becoming more attractive and time saving in information searching and retrieval. It is becoming impossible to have access to information without the help of ICT, hence, cost implications of use of ICT for processing and resource sharing. ICT tools that have impacted on library job operations is the Online databases services. It has opened up a lot of resources for librarians to have access to. Some can be accessed free of charge, while others are subscribed to by universities or organizations before users can have access to these resources online. There are large numbers of databases that can be searched for at no cost. Universities in developing nations and international organizations such as the World Health Organization (WHO) provide free access databases to higher institutions and research centers to support teaching, learning and research work. This is done through subsidizing payment of online databases such as HINARI,
AGORA and OARE to research centers, colleges and universities (Research4life, 2012).

Online database service are large collection of information resources or files organized in an electronic format, updated regularly to maintain its currency and relevance and related to a particular discipline or subject organized for easy and speedy searching and retrieval. The content of databases includes bibliographic records such as directory entries, images, full-text, statistics, etc linked with definite discipline and well organized for speedy access and easy retrieval of information.

Digital libraries providing the full-text of the indexed contents evolving from bibliographic databases and usually focused on a particular field of knowledge with various types of publications. Using keyword, abstracts and division by sub-themes, bibliographic databases to enable relevant information sources targeted research areas. The bibliographic databases are offered from the Library web pages. For example, bibliographic databases are organized to enhance easy and speedy access and retrieval of the information kept therein.

Full-text database contains complete text of books, dissertations, newspaper and other textual documents but does not include graphical documents such as pictures and diagrams. Document that has being referenced can be highlighted and retrieved online. It is also searchable by using keywords to retrieve it or use phrases that are close in meaning to retrieve it. Word-processed file requiring software programs like MS Word are presented on full-text document and on PDF formats. Full-text databases are commonly used by staff and library users for their convenience in the library. Also, they suite classrooms operating online and allow users to access materials remotely at the comfort of their homes and offices using internet connectivity.

Hybrid databases utilizes both on-disk and inmemory data storage devices. Hybrids are utilized with high performance databases with small footprint that only in-memory database systems can provide. The system makes use of hard disk for saving and retaining data. Online databases conserve storage space, allow for faster searching and easier modification of records. It explains current acquisitions on display and individual copies of tittles in circulation. The operation of this database service is facilitated through customized database management software. There are software packages that libraries adopt in their inhouse routine work, the software packages that 
are commonly used by librarians are "ALICE for Windows, CD-ISIS, E-Lib, GLAS, Tin-Lib, SLAM, $\mathrm{X}$-Lib and Virtual".

Utilization of CD-ROM services provides faster and a better service to library users. Today, the CD-ROM service is the most modern information and communication technology tools that are replacing preservation practices. Librarians can store their information on the CD-ROM databases with ease than the internet. This is because the CD-ROM retrieval rate is not affected by slowness that libraries experience on the internet during heavily used time periods by users. The data stored can easily be read by means of computer enabled CD-ROM drive.

Librarians' job operations today are more than shelving of books. With the increase in the population size of library users, libraries are providing users with new dimensions of information dissemination such as use of CDROM and other electronic formats in accessing information resources. Hard disk drive is another smaller storage tool. It is a non-volatile memory hardware device that permanently store and retrieves information. When data is saved to the computer or installing programs, the hard disk writes the information. Flopping disk is also among the storage library tools in computer system that comes with magnetic storage. For you to be able to read and write data from a flopping disk, it requires a computer system that must have a flopping disk drive (FDD). Back-up copies of data and partitioning of files can be created with a floppy disk.

The Nigerian government has done its best in advancing to the current innovations. For instance, the Federal Government through the Ministry of Education and the National Universities Commission (NUC) has done a lot in terms of subsidizing subscriptions to databases to universities, organized series of workshops for capacity building on ICT 2012 to support the implementation and development of virtual libraries. With the subsidization of subscription of databases, one would expect a more integration and utilization of ICT facilities into job operations in the provision and utilization of library resources and services. These lapses are limiting librarians access to gaining and utilizing information resources thereby limiting job effectiveness, efficiency and performance.

The application of information and communication technology therefore is essential in boosting morale of librarians in their day-to-day job operations as it is also necessary to develop positive attitude towards technology utilization.
The present study therefore seeks to investigate utilization of information and communication technology on library job operations in state university libraries in South-South Nigeria.

\section{STATEMENT OF THE PROBLEM}

Attention on university library services are gearing towards the area of ICT as a result of the changing pattern of the information seeking behaviour of information users. Preliminary observations have shown that state university libraries in South-South Nigeria has, up to 2015, been totally reliant on performing their routine library job operations manually. The issue of poor performance of libraries in state university libraries has been a long-standing problem that has received concern of government and other stakeholders. The poor performance has been characterized with capital investment on information and communication technology equipment, high cost of library software and database connectivity, maintenance low patronage of ICT services, lack of interest in utilizing ICT on library job operations, shortage of skilled ICT manpower and good remunerations to retain the few skilled ones, and constant epileptic power supply amongst others.

Whether the utilization of ICT on library operations could remedy the manual system and bring about effectiveness, efficiency and performance in library operations is the concern for this study. This is more so in the absence of any specific research evidence in this specific area. The present study put in question is: what is the level of utilization of ICT on library job operations in state university libraries in SouthSouth Nigeria?

\section{STATEMENT OF HYPOTHESES}

In determining the utilization of information and communication technology (ICT) on library job operations, two hypotheses were tested: -

1. There is no significant influence of use of online databases services on library job operations;

2. Use of CD-ROM services does not significantly influence library job operations.

\section{LITERATURE REVIEW}

Libraries are well equipped with the necessary information guidelines as it relates to library job operations. Librarians go as far as searching through online databases and CD-ROMs for current and up-to-date resources. Online databases constitute a major service that is very useful in modern day library job operations for 
service delivery. In Nigeria, the National University Commission (2010) reported that Educational Trust Found(ETF) now known as Tertiary Education Trust Fund (Tetfund) have been able to subsidize the payment of online databases such as Ebsco Host resources for State Universities, Polytechnics and Colleges of Education. The databases in libraries has become an opportunity open for state university libraries in developing nations like Nigeria to bridge the knowledge gap and move towards a digital knowledge-based society. As a result of this, libraries in developing countries opt for free databases on the internet, such as the open access journals. Open access is free of charge for readers that are registered with the resource databases. They allow library users to freely read, download copy and acknowledge the author in their work (Kwan, 2003; Ricardo and Merce 2004).

Similarly, the study of Paines and Kwachi (2013) showed that majority of the database subscribed to by the university were HINARI, JSTOR, OARE, AGORA, Ebsco host resources, TEEAL,DOAJ, MIT Open Course ware, Proquest, Science Direct and Elsevier EIR databases in Kurukshetra University library, India. It was also discovered that the duration of subscription of these resources range from 2- 3 years, while some of these databases were free.

Lawal (2014) study revealed that the "University of Calabar has subscribed to a number of online databases such as AGORA, HINARI, and EBSCO host for its numerous users. The Libraries has also linked up with the National University Commission (NUC) to subscribe to the relevant e-books/e-journals towards effective developments of its virtual Library system". In view of the fact that there are varieties of online databases across all academic disciplines/fields, the University of Calabar is subscribed to only EBSCO HOST that is provided by NULIB/NUC. Lawal (2014) findings further revealed that Science Direct $(38.8 \%)$ is the database that is mostly accessed and used by respondents in their teaching/research, followed by EBSCO HOST (11.8\%) and AGORA (11.8\%) respectively. The respondents also mentioned Scopus, AGRICOLA, SciFinder, ASAS, 2MASS, World Bank Publications, SAGE publications, Elsevier, Google, Yahoo, Sinbad and Chemical Structure Database. Online database improves educational outcome in teaching and research. It was recommended that online databases are eminent in view of the fact that staff needs information in this emerging information environment.

James (2014) study on availability of EIR databases in three higher institutions in South Africa, showed that University of Johannesburg had 160 databases, Nelson Mandela Metropolitan University had 40 and Cape Peninsula University of Technology had 100 edatabase resources in their universities

Also, the study conducted by Akinseye (2014) observed that many university libraries have subscribed 2-3 years online databases for lecturers and students in order to have access to information and to updating their knowledge for the purposes of teaching, learning and reach work. Similarly, Otokune for and Kari (2008) and Nok (2006) study carried out showed that these libraries in Nigeria are gradually developing their electronic resource databases collection and the major data bases that could be found are Access to Global Online Research in Agriculture (AGORA), Health Internetwork Access to Research Initiative (HINARI) and Online Access to Research in the Environment (OARE), Directory of Open Access Journal (DOAJ) and EBSCO host resources. It could be possible because they are free access databases that are made available for developing nations like Nigeria. Each of these databases consist of different titles of peer reviewed journals, books and other educative resources.

Tiemo (2016) conducted a study on availability of electronic information resource databases in university libraries in South-South, Nigeria. To determine the available EIR databases in federal and state university libraries, the system librarians were asked to indicate the various types of database that are available in their library. Their responses showed that of the 22 types of EIR database listed, the federal universities had 17 namely: AGORA, HINARI, EBSCO host resources, AJO, OARE, DATAD, TEEAL, INASP, MIT Open Course Ware, DOAJ, JSTOR, World Public Library, Lexis-Nexis, Questia, E-library. The state universities in South-South, Nigeria had 12 namely: AGORA, HINARI, EBSCO host Resources, AJOL, OARE, TEEAL, DOAJ, JSTOR, E-library, Oxford online journal, Biomed central, Aluka Publication and are available. Based on the findings of this study, it was recommended among others that university libraries should be well funded in order to subscribe to more fee based EIR databases that are relevant to the teaching, learning and research work in their libraries. 
Ani and Edem (2012) conducted a survey to explore the Access and Usage of Online Database Staff in University of Calabar, Nigeria. Observations shows the respondents are accessing and using online databases occasionally $(48.1 \%)$. $(29.6 \%)$ use it weekly while $(7.4 \%)$ use it daily. The result shows low frequency of access and usage of online databases.

Bassi and Camble (2011) conducted a study on use of electronic resources and gender equality in university libraries of Adamawa State, Nigeria. The research highlights internet being the outstanding information tool utilized. Other online tools on the web representing three libraries with $392(41.5 \%), \quad 165(17.23 \%)$ and $125(13.09 \%)$ representing e-books, and e-journals with Database standing at $116(12.15 \%)$ respectively. The study recommends that library management needs online resources and to sustain its existence specifically computer. Databases are provided at a very subsidized rate with little fee charged by libraries in developing countries to help in maintenance purposes while others require subscription fee.

Krubu and Osawaru (2011) conducted a research impact on information and communication in Nigeria university libraries. Findings revealed $18(38.0 \%)$ of respondents utilized CD-ROM, 10 $(21.0 \%)$ respondents utilize online database, internet and search engine utilized 8(14.6) and $5(10.4 \%)$ respectively. It is concluded that majority of the respondents utilized CD-ROM. In another study, Egunjobi (2006) on ICT Application in Nigerian Colleges of Education Libraries indicated that 20 federal colleges were used and twelve (12) completed and returned their questionnaires. Result revealed that $41 \%$ have embarked automation, but there was no access to internet and $16 \%$ provide CD-ROM databases for their users. It further revealed that $50 \%$ use X-Lib as the most popular software.

Oyewusi and Oyeboade (2009) conducted the research on use of library resources by undergraduates in a Nigerian state university of technology. The result indicated $94.4 \%$ respondents have access to photocopy machine while some indicated electronic databases, OPAC, e-journal and Facsimile do not have access. $3(0.8 \%)$ respondents indicated access to CD-ROM. The libraries are still making efforts to acquiring those electronic tools during the research process as a result. The study recommended that administrators and decisionmakers must evaluations their library resources for improved services delivery. Enough funding for the university libraries help maintain its digital resources.

\section{RESEARCH METHODOLOGY}

A survey research approach was advocated for the study as the research method. Professional and Para-professional librarians from four State Universities (Cross River State University of Technology, Akwa-lbom State University, NigerDelta University and Delta State University)were used as respondents in the study as shown in Table 1. Split-half reliability technique was adopted to test the internal consistency. The study population (SP) from the four state university libraries was 143 librarians while the samplewas 93 representing $65 \%$ of the professional and paraprofessionals from each of the four selected state universities in SouthSouth Nigeria. Thus, 32 from Cross River State University of Technology, 30from Akwa-Ibom State University, 16fromNiger-Delta University and 15 from Delta State University were used in the study. And, similarly, a validated researchers' made instrument (questionnaire) was used for data collection. A reliability index of 0.78 was achieved for the instrument using Cronbach Alpha method after a pilot test was conducted on 40 respondents that were not part of the main study. The respondents were also asked to respond to questions to explore the extent of Utilization of ICT on library operations in state university libraries in South-South Nigeria. The sampled93 respondents drawn from the population were used for data analysis. 
Findings and Discussion

TABLE 1

Population and sample of librarians in State University Libraries in South-South Nigeria

\begin{tabular}{|c|l|c|c|c|c|c|c|}
\hline & \multicolumn{3}{|l|}{$\begin{array}{l}\text { POPULATION OF LIBRARIANS IN STATE } \\
\text { UNIVERSITY LIBRARIES IN SOUTH-SOUTH }\end{array}$} & \multicolumn{3}{l|}{$\begin{array}{l}\text { SAMPLE OF LIBRARIANS IN STATE } \\
\text { UNIVERSITY LIBRARIES IN SOUTH-SOUTH }\end{array}$} \\
\hline S/N & Universities & Professional & Paraprofessional & Total & Professional & Paraprofessional & Total \\
\hline 1 & $\begin{array}{l}\text { Cross River } \\
\text { University of } \\
\text { Technology }\end{array}$ & 32 & 16 & 48 & 21 & 10 & 31 \\
\hline 2 & $\begin{array}{l}\text { Akwa-lbom } \\
\text { State } \\
\text { University }\end{array}$ & 30 & 12 & 42 & 20 & 8 & 28 \\
\hline 3 & $\begin{array}{l}\text { Niger Delta } \\
\text { University }\end{array}$ & 16 & 10 & 26 & 10 & 7 & 17 \\
\hline 4 & $\begin{array}{l}\text { Delta State } \\
\text { University }\end{array}$ & 15 & 12 & 27 & 9 & 8 & 17 \\
\hline & Total & 93 & 50 & 143 & 60 & 33 & 93 \\
\hline
\end{tabular}

The main dependent variable of the study was library job operations. The mean and standard deviation of the major variables of the study was calculated and presented as shown below. A total of ninety-three hundred (93) respondents were used for the study. Each hypothesis was stated in null form. The result of data analysis tested is presented. Each hypothesis was tested at .05 level of significance.

\section{TESTING OF HYPOTHESES}

HYPOTHESIS 1: There is no significant influence of use of online database services on library job operations in state university libraries in South-South Nigeria.

\section{TABLE 2}

One-Way ANOVA with the influence of use of online databases services on library job operations

\begin{tabular}{|c|c|c|c|c|c|}
\hline Sources of variance & Sum of squares & df & Mean square & F-value & Sig. \\
\hline Between Group & 46.250 & 2 & 23.125 & & \\
\hline With Groups & 468.030 & 90 & 5.200 & $4.447^{*}$ & .014 \\
\hline Total & 514.280 & 92 & & & \\
\hline
\end{tabular}

The table clearly shows the summary of One-way Analysis of variance with the influence of use of online database services on library job operations. Between and within group sum of squares are 46.250 and 468.030 ; at 2 and 92 degrees of freedom, the mean squares between and within are 23.125 and 5.200 , with a Fishers calculated value of 4.447 that was greater than critical F-value of 3.00. Therefore, null hypothesis of no significant influence of use of online database services on library job operations was rejected $(F=4.447 ; P=.014)$. The implication is that, there is a significant influence of use of online database services on library job operations. 
TABLE 3

Descriptive Statistics

\begin{tabular}{llll}
\hline Online databases & $\mathrm{N}$ & $\overline{\mathrm{X}}$ & $\mathrm{SD}$ \\
& & & \\
\hline Full-text database & 61 & 12.8852 & 2.35 \\
Bibliographic database & 24 & 14.4583 & 2.21 \\
Hybrid database & 8 & 12.6250 & 1.92 \\
Total & 93 & 13.2688 & 2.36 \\
\hline
\end{tabular}

It is evident from Table 3 with the descriptive statistics that the total of 61 librarians utilized Full-text databases with a mean and standard deviation of 12.8852 and 2.35. Bibliographic database constituted 24 respondents with mean of 14.4583 and standard deviation of 2.21. While Hybrid databases had 8 respondents with mean and standard deviation of 12.6250 and 1.92 respectively.

HYPOTHESIS TWO: Use of CD-ROM services does not significantly influence library job operations.

TABLE 4

One-Way ANOVA with influence of use of CD-ROM services on library job operations

\begin{tabular}{|c|c|c|c|c|c|}
\hline $\begin{array}{ll}\begin{array}{l}\text { Sources } \\
\text { variance }\end{array} & \text { of } \\
\end{array}$ & Sum of squares & $\mathrm{df}$ & Mean square & F-value & Sig. \\
\hline Between Group & 36.20 & 2 & 18.100 & \multirow{2}{*}{$2.671^{*}$} & \multirow{2}{*}{.075} \\
\hline $\begin{array}{l}\text { With Groups } \\
\text { Total }\end{array}$ & $\begin{array}{l}609.87 \\
646.07 \\
\end{array}$ & $\begin{array}{l}90 \\
92\end{array}$ & 6.776 & & \\
\hline
\end{tabular}

It can also be discerned from the One-way Analysis of variance summary with influence of use of CD-ROM services on library job operations. Between and within group sum of squares are 36.20 and 609.87 ; at 2 and 92 degrees of freedom, the mean squares between and within are 18.100and 6.776, with a Fishers calculated value of 2.671 was greater than critical F-value of 3.00. Therefore, the null hypothesis of no significant influence of use of CD-ROM services on library job operations is rejected. $(\mathrm{F}=2.671 ; \mathrm{P}=.075)$. This implies that, there is a significant influence of use of CD-ROM services on library job operations.

TABLE 5

Descriptive Statistics

\begin{tabular}{llll}
\hline CD-ROM Services & $\mathrm{N}$ & $\mathrm{X}$ & $\mathrm{SD}$ \\
\hline Hard Disc Drive & 69 & 13.09 & 2.55 \\
Floppy Disc Drive & 17 & 14.71 & 2.59 \\
Flash derive & 7 & 13.14 & 3.18 \\
Total & 93 & 13.39 & 2.65 \\
\hline
\end{tabular}

The analysis in Table 5 shows the descriptive statistics with a total of 88 librarians utilized Hard Disc Drive with a mean of 13.09and 2.55. Floppy Disc Drive constituted 17 respondents with mean of 14.71 and standard deviation of 2.59. Flash drive had 7 respondents with mean and standard deviation of 13.14 and 2.65 respectively. 


\section{DISCUSSION}

The first findings of the study showed that there is a significant influence of use of online databases services on library job operations. This is because the way librarians organize their job operations for academic performance could be considered very crucial to their overall performance. The finding of the present study agrees with that of Ani and Edem (2012) findings that showed the respondents are accessing and using online databases occasionally $(48.1 \%)$. $(29.6 \%)$ use it weekly while $(7.4 \%)$ use it daily. The result shows low frequency of access and usage of online databases.

In view of the fact that there are varieties of online databases across all academic disciplines/fields, the study also is in harmony with that by Lawal (2014) whose findings indicated that the University of Calabar is subscribed to only utilize EBSCO Host that is provided by NULIB/NUC. Science Direct $(38.8 \%)$ is the database that is mostly accessed and used by the respondents in their teaching/research followed by EBSCO HOST (11.8\%) and AGORA $(11.8 \%)$ respectively. Online database improves educational outcome in teaching and research. The study recommended that online databases are eminent in view of the fact that staff needs information in this emerging information environment in the university of Calabar, Nigeria.

The present finding is in harmony with that of Paines and Kwachi (2013) showed that majority of the databases subscribed to by the university were HINARI, JSTOR, OARE, AGORA, Ebsco Host resources, TEEAL, DOAJ, MIT Open Course ware, ProQuest, Science Direct and Elsevier EIR databases in Kurukshetra University library, India. It was also discovered that the duration of subscription of these resources range from 2- 3 years, while some of these databases were free.

The result of the finding of hypothesis two shows that use of CD-ROM services significantly influences library job operations. The CD-ROM service is among most modern information and communication technology tools that are replacing preservation practices in libraries. Librarians' job operations today are more than shelving of books. The study is in consonance with that of Krubu and Osawaru (2011) study conducted on the impact of information and communication in Nigeria university libraries. Findings revealed $18(38.0 \%)$ of respondents utilized CD-ROM, 10 (21.0\%) respondents utilize online database, internet and search engine utilized $8(14.6)$ and $5(10.4 \%)$ respectively. It is concluded that majority of the respondents utilized CD-ROM. The study indicated low utilization of CD-ROM. In another study, Egunjobi (2006) on ICT Application in Nigerian Colleges of Education Libraries indicated that 20 federal colleges were used and twelve (12) completed and returned their questionnaires. Result reveal that $41 \%$ have embarked automation, but there was no access to internet and $16 \%$ provide CDROM databases for their users. It further revealed that $50 \%$ use XLib as the most popular software.

Also, Oyewusi and Oyeboade (2009) conducted the research on use of library resources by undergraduates in a Nigerian state university of technology. The result indicated $94.4 \%$ respondents have access to photocopy machine while some indicated electronic databases, OPAC, e-journal and Facsimile do not have access. $3(0.8 \%)$ respondents indicated access to CD-ROM indicating low response rate of CDROM.

\section{CONCLUSION}

Based on the results of the study the following conclusions were reached.

1. Librarians do not adequately utilize ICT on their library job operations in state university libraries in South-South Nigeria;

2. Despite all the efforts made so far by agencies such as TETFUND to provide databases in universities, the availability of databases in the state university libraries in South-South, Nigeria is still very low. This indicate that librarians in the state universities may not be well exposed to free based databases that can be used to develop their eresources for teaching, learning and research work.

3. Facilities are inadequate, lack of competent ICT technologist and epileptic power supply.

\section{RECOMMENDATIONS}

Based on the result of the study, it was recommended that:

1. Librarians should be made to avail themselves the opportunity of accessing the available online databases services to their own advantage to enable them perform their routine job operations effectively and with ease; 
2. Also, librarians should be trained on how to utilize the modern ICT tools such as online databases and CD-ROM services on library job operations through attending workshops seminars, conferences and symposiums to better their skills and also project their library products and services.

\section{REFERENCES}

Ani, O. E. and Edem, N., 2012. Access and usage of online databases in Nigeria universities in teaching/research: A study of academic staff in university of calabar, calabar, Nigeria. Library and Information Practitioner. Journal of Nigeria Library Association Cross River State chapter, 5 (2), 75-484.

Ani, O. E., Esin, J. E. and Edem N., 2005. Adoption of Information and communication technology (ICT) in academic libraries: A strategy for library networking in Nigeria. The electronic library journal 23(6), 701-708.

Akinseye, O. B., 2014. Use of ICT facilities in higher institutions for learning. Journal of Social Science. 23(12), 78-85.

Bassi, M. D. and Camble, E., 2011. Gender differences in use of electronic resources in university libraries of Adamawa State, Nigeria. 4-7.

Edem, N. B. and Ani, O. E., 2015. Development of electronic libraries in Nigerian universities. Information technologist 12 (2), 35-45.

Egunjobi, R. A., 2006. Information technology application in Nigeria college of education libraries. Gateway Library Journal, 9 (1), 12-22.

James, B. I., 2014. Availability of e- databases in three higher institutions in South Africa: A study of University of Johannesburg, Nelson Mandela Metropolitan University and Cape Peninsula University of technology university e- libraries. Journal of Adult Education and Sustainable Development, 6(5)34-39.

Krubu, D. E. and Osawaru, K. E., 2011. The impact of information and communication technology in Nigerian university libraries. Journal of Humanities 8 (6), 1213.

Kwan, J., 2003. What is open access and why should you care? Retrieved June13th, 2016

from:

http://nnlm.gov/psr/lat/v12n3/openaccess

.html

Lawal, O. O., 2014. The tree of knowledge: Dynamics of academic libraries in information management. Being the 58th Inaugural Lecture. University of Calabar, Calabar: University of Calabar press. 529.

National Universities Commission. 2010. Providing information resources to universities in Nigeria. Annual Review on ICT in universities 2010.

Nok, G., 2006. The challenges of computerizing a University library in Nigeria: the case of Kashim Ibrahim Library, Ahmadu Bello University, Zaria. Library Philosophy and Practice, 8(2). Retrieved on March 15th, 2016 from http://www.webpages.uidaho.edu/ mboli n/nok.htm.

Nkoyo, E., Emmanuel, U. O. and Abel, U., 2017. Utilization of Information and Communication Technology (ICT) and Collection Management Practices in University Libraries in South-South Nigeria. International information management association conference and international conference on information technology and economic development held at the university of the west of Scotland from 11th-13th September, 2017.

Otokunefor, H.O.C. and Kari, H. K., 2008. Issues, controversies and problems of cybercafés located in a university campus. In E.E Adomi (Ed.), security and software for cybercafé. Pp.62 -83. New York: IGI Global.

Oyewusi, F. O. and Oyeboade, S. A., 2009. An empirical study of accessibility and use of library resources by undergraduates in a Nigerian state university of technology. Available at http: 
www.webpages.uidaho.edu/mbolin/oyew usi-oyeboade.htm.

Paines, B. N. and Kwachi. O. P., 2013. Utilization of electronic databases among students in Kurukshetra University Library, India. International Journal of Gender and development, 15(12), 38-47.

Research4life., 2012. Developing world access to leading research. Retrieved August 13th, 2016 from http://www.research4life.org/about.html.
Ricardo, G. and Merce, P., 2004. Open access. A turning point in scientific publication. International Microbiology. 7(3). Retrieved April26th, 2018 from http://revistes.iec.cat/index.php//M/article/ view/4c457c68ec12a.002/9462

Tiemo, P. A., 2016. Availability of electronic information resource databases in university libraries in south-south, Nigeria. European Centre for Research Training and Development,4(13), 77-89. 